7. Карпухин А.Е., Алексеева Е.С. «Слепой» траст («blind» trust) как метод предотвращения конфликта интересов. Акционерное общесство: вопросы корпоративного управления. 2020. № 07 (194).

8. Буяджи Г. Сліпий траст: інструмент приховування майна чи механізм усунення конфлікту інтересів? Підприємництво, господарство і право. 2018. № 2. С. 4-8.

9. Буяджи Г. Багатоюрисдикційні, міжнародні та офшорні трасти. Проблемні питання співвідношення понять. Право Украйни. 2018. № 1. C. $232-250$.

DOI https://doi.org/10.30525/978-9934-588-92-1-44

\title{
ПРАВОВИЙ АНАЛІЗ ІНСТИТУТУ ЛІЦЕНЗУВАННЯ ПІДПРИЕМНИЦЬКОЇ ДІЯЛЬНОСТІ
}

\begin{abstract}
Можайкіна О. С.
кандидат психологічних наук, дочент, доцент кафедри міжнародного, ичивільного та комериійного права Київського начіонального торговельно-економічного університету м. Київ, Украӥна
\end{abstract}

Інститут ліцензування підприємницької діяльності з'явився у вітчизняному законодавстві відносно недавно. У червні 2000 року було прийнято Закон України «Про ліцензування певних видів господарської діяльності». Подальший розвиток зазначеного інституту носить стрімкий характер: за минулий період було прийнято велику кількість змін і доповнень до загального закону, а також прийняті інші законодавчі та підзаконні нормативно-правові акти, з'явилася суттєва судова практика. Однак, правові механізми ліцензування підприємницької діяльності постійно критикувалися вітчизняними вченими. Варто звернути увагу на те, що у березні 2015 року було прийнято новий Закон України «Про ліцензування видів господарської діяльності», який $є$ наразі чинним.

Особливої уваги потребує зміст правовідносин у сфері ліцензування, a також його мета та завдання. Стаття 1 Закону України «Про ліцензування видів господарської діяльності» (далі - Закон) визначає, що ліцензування $є$ засобом державного регулювання провадження видів господарської діяльності, спрямований на забезпечення безпеки та захисту економічних і соціальних інтересів держави, суспільства. Прав та 
законних інтересів, життя і здоров'я людини, екологічної безпеки та охорони навколишнього природного середовища [1].

Досліджуючи питання правової природи ліцензування господарської діяльності К.А. Карчевський виділяє характерні ознаки ліцензування господарської діяльності, такі як: 1) ліцензування, насамперед, передбачає надання дозволу на заняття певним видом (видами) господарської (підприємницької) діяльності; 2) ліцензування - це діяльність, яка пов'язується з видачею ліцензій та вчинення інших дій, що пов'язані з видачею ліцензій (ліцензійних дій); 3) ліцензування провадиться тільки уповноваженими на це державними органами; 4) ліцензії видаються тільки певним особам; 5) ліцензуванню підлягають тільки певні види господарської діяльності; 6) ліцензування - це надання дозволу на певний строк; 7) ліцензування - це надання дозволу за певних умов [2, с. 183$]$.

В той же час Я.Л. Коломієць стверджує, що ознаками, які характеризують ліцензування є: 1) діяльність уповноважених державних органів щодо засвідчення права на зайняття певним видом господарської діяльності конкретного сільськогосподарського товаровиробника; 2) має форму персоніфікованого імперативного припису, який зобов'язує суб'єкта аграрного господарювання сільськогосподарського товаровиробника діяти в чітко визначених межах, що забезпечується встановленням ліцензійних умов; 3) ліцензування $\epsilon$ засобом державного регулювання, що полягає в контролі за додержанням останніх i вжиттям заходів 3 усунення порушень законодавства у сфері ліцензування [3, с. 119].

Привертає увагу також думка А.I. Шпомер, яка відносить до ознак ліцензування господарської діяльності такі як: публічний (державний) характер ліцензування; процесуальний характер ліцензування; єдність ліцензування, під яким автор розуміє, що процес ліцензування регламентується законодавчими актами і є єдиним на всій території держави; обов'язок ліцензування. Як видно 3 наведеного вище, українські вчені у переважній більшості виділяють однакові за змістом ознаки ліцензування підприємницької діяльності [4, с. 135].

Варто також звернути увагу на законодавчо закріплені принципи ліцензування, які містяться у ст.3 Закону. До основних принципів державної політики у сфері ліцензування відносяться:

- принцип єдиної державної системи ліцензування;

- принцип територіальності;

- принцип дотримання законності; 
- принцип пріоритетності захисту прав, законних інтересів, життя i здоров'я людини, навколишнього природного середовища, захисту обмежених ресурсів держави та забезпечення безпеки держави;

- принцип рівності прав суб'єктів господарювання;

- принцип відкритості процесу ліцензування [1].

Аналіз зазначених принципів дає підстави стверджувати, що вони в більшій мірі носять публічний характер i відносяться до сфери діяльності органів державної влади, яким надано повноваження щодо видачі ліцензій суб'єктам господарювання. Однак, вважаємо за необхідне звернути увагу, що на даний час вчені-правники не мають єдиної позиції щодо віднесення інституту ліцензування до певної галузі. Господарське право, що тісно взаємопов'яане 3 цивільним, адміністративним та конституційним право, відносить ліцензування до своєї сфери регулювання, оскільки включає в себе сукупність норм права, які регулюють господарські (підприємницькі) відносини. Зокрема до таких відносин належать реєстрація юридичних осіб та фізичних осіб-підприємців, припинення діяльності господарюючих суб'єктів, а також ліцензування, яке, на наш погляд, i не носить підприємницький характер, але складає передумови для подальшого здійснення підприємницької діяльності. Про це свідчить зміст ст. 3 Господарського кодексу України (далі - ГКУ), в якій зазначено, що до сфери господарських відносин належать організаційно-господарські відносини, що складаються між суб'єктами господарювання та суб'єктами організаційно-господарських повноважень. Крім цього, ст. 14 ГКУ визначає ліцензування засобом державного регулювання у сфері господарювання, спрямованими на забезпечення єдиної державної політики у цій сфері та захист економічних і соціальних інтересів держави, суспільства та окремих споживачів [5].

Аналіз норм Закону та ГКУ показує, що визначення ліцензування $\epsilon$ уніфікованим. Однак, на відміну від Закону, ст. 14 Господарського кодексу України дає лише загальне уявлення про ліцензування господарської діяльності. Детальніше визначення міститься в Законі. Однак, варто зауважити, що Законом передбачено 31 вид діяльності, які підлягають ліцензуванню. То ж ліцензійні умови здійснення кожного із зазначених у ст. 7 Закону виду діяльності визначені в окремих нормативно-правових актах.

Ретроспективний аналіз законодавства у сфері ліцензування підприємницької діяльності показує, що поняття ліцензї не було сталим. Так, в Законі України «Про ліцензування певних видів господарської діяльності», який діяв до прийняття Закону від 02.03.2015 р. ліцензією визнавався документ державного зразка, який 184 
засвідчує право ліцензіата на провадження зазначеного в ньому виду господарської діяльності. Після прийняття нового Закону ліцензією визнавався запис у Сдиному державному реєстрі юридичних осіб, фізичних осіб - підприємців та громадських формувань про рішення органу ліцензування щодо наявності у суб'єкта господарювання права на провадження визначеного ним виду господарської діяльності, що підлягає ліцензуванню. У 2019 році були прийняті зміни і доповнення до Закону, які стосувалися і самого визначення ліцензії, під якою наразі розуміється право суб'єкта господарювання на провадження виду господарської діяльності або частини виду господарської діяльності, що підлягає ліцензуванню [1]. Тобто, остання редакція Закону визначає ліцензію як право, а не як спеціальний дозвіл або документ, який встановлює (підтверджує) відповідне право суб'єкта господарювання. Вважаємо, що чинне визначення ліцензії є недосить вдалим і не в повній мірі співвідноситься 3 іншими підзаконними нормативноправовими актами, які регулюють питання ліцензування окремих видів підприємницької діяльності. Так, наприклад, п.46 Ліцензійних умов провадження освітньої діяльності закладів освіти, затверджених постановою Кабінету Міністрів України від 30.12.2015 p. № 1187, передбачено, що здобувач ліцензії (ліцензіат) повинен подати Міністерству освіти і науки України заяву про отримання ліцензії (про розширення освітньої діяльності). Таким чином стає зрозумілим, що мова йде про певний документ, який встановлює відповідне право ліцензіата.

Аналіз чинного вітчизняного законодавства та наукової літератури у галузі ліцензування підприємницької діяльності дає підстави висновувати, що окремі аспекти, поняття, категорії та визначення потребують подальшого вивчення та удосконалення. Чіткі нормативноправові дефініції дозволять уникнути допущення помилок при їх практичному застосуванні та неоднозначності трактування.

\section{Література:}

1. Про ліцензування видів господарської діяльності: Закон України від 02 березня 2015 р. № 222-VIII / Верховна Рада України. URL: http://zakon2.rada.gov.ua/laws/show/222-19.

2. Карчевський К.А. Ліцензування господарської діяльності: правова природа, джерела правового регулювання, поняття та ознаки. Вісник Харківського начіонального університету внутрішніх справ. 2009. № 44. C. 180-188. 
3. Коломієць Я.Л. Правове регулювання обмежень у здійсненні виробничо-господарської діяльності сільськогосподарських товаровиробників: дис. ... канд. юрид. наук: 12.00.06. Харків, 2015. 214 с.

4. Шпомер А.І. Ліцензування господарської діяльності (господарсько-правовий аспект): дис. ... канд. юрид. наук: 12.00.04. Київ, 2006. $232 \mathrm{c}$.

5. Господарський кодекс України: Закон України від 16.01.2003 р. № 436-IV / Верховна Рада України. URL: http://zakon2.rada.gov.ua/ laws/show/436-15.

DOI https://doi.org/10.30525/978-9934-588-92-1-45

\title{
PROBLEMATIC ISSUES OF LEGAL TERMINATION OF CRYPTOCURRENCIES
}

\author{
Polishchuk N. Yu. \\ Postgraduate Student \\ V. Mamutov Institute of Economic and Legal Research \\ of the National Academy of Sciences of Ukraine \\ Kyiv, Ukraine
}

In recent years, in the development of the world economy in general and its financial system in particular, we have seen phenomenal changes and transformations associated with the emergence of cryptocurrencies. The question is whether the cryptocurrency can cease to exist, as well as whether there is a legal explanation for this. As there is currently no unified legal regulation of cryptocurrencies, the possible reasons for terminating cryptocurrencies should be taken into account when drafting legislation. It is extremely difficult to manipulate the cryptocurrency network. Deleting or overwriting a block of already spent bitcoins becomes impossible due to decentralization, chronological and computational, energy-intensive characteristics of the blockchain. A hacker who wants to change a distributed bitcoin book or any other network based on blockchain technology will have to hack not one, but more than half of the participating computers, the so-called «51\% attack», in which a group of miners theoretically controls more half of the total network capacity. By running most of the entire network, this criminal group of hackers can dominate the rest of the network to falsify records. However, such an attack on 